\title{
Pier scouring reduction using a Strip Guide Flow Panel device
}

\author{
Ihsan A. Abdulhussein, Rafi M. Qasim \\ Southern Technical University, Al-Zubair Road, Basrah, Republic of Iraq
}

Khalid Al-Asadi

University of Basrah, Karmat Ali Road, Basrah, Republic of Iraq

\author{
Article history: \\ Received: June 01, 2019 \\ Revised: July 27, 2019 \\ Accepted: September 06, 2019
}

\section{Keywords:}

scour reduction, bridge piers, hydraulic structures
A set of laboratory experiments were conducted to study the effect of using a Strip Guide Flow Panel device to reduce scour process effects around a bridge pier. Three cylindrical piers of different diameter values and three different Strip Guide Flow Panel devices were used. Every Strip Guide Flow Panel device is simulated by two arms connected together at one of their edges at a right angle. The length of every arm is selected in a way to cover the pier diameter. Every Strip Guide Flow Panel was mounted on the upstream face of the corresponding cylindrical pier diameter at elevation adjacent to the flume bed. A uniform sized sediment were used as a bed material. Based on the experimental data, an acceptable range of scour reduction efficiency (35.71-66.67\%) and high hydraulic safety factors were obtained when using Strip Guide Flow Panel. Also it is found that the scour depth when using Strip Guide Flow Panel is small comparing with corresponding potential and maximum scour depth values. So it can be concluded that the Strip Guide Flow Panel device can work like a turbulence kinetic energy dissipater to reduce the risk of scour around the pier during the serviceability life of bridge structure.

\section{Introduction}

Local scouring around bridge piers is considered the most risky problem that affects the bridge safety. In order to decrease the effect of this problem, extensive efforts have been spent to develop

Ihsan A. Abdulhussein, Assistant Professor of Department of Environment and Pollution, Basrah Engineering Technical College, Southern Technical University, Ph.D.; drengihssan@stu.edu.iq

Khalid Al-Asadi, lecturer of Civil Engineering Department, College of Engineering, University of Basrah, Ph.D.

Rafi M. Qasim, lecturer of Department of Environment and Pollution, Basrah Engineering Technical College, Southern Technical University, M.Sc.

(C) Abdulhussein I.A., Al-Asadi K., Qasim R.M., 2019

This work is licensed under a Creative Commons Attribution 4.0

(c) (i) International License

https://creativecommons.org/licenses/by/4.0/ suitable scour reduction measures. The main purpose for developing these scour reduction measures is to increase the resistance against the scour phenomena and modifying the flow. Reference [1] has classified the scour reduction measures into two types; the first type is flow altering reduction measure, whereas the second is bed armoring reduction measure. The study has focused on an application of the flow altering scour reduction measure.

To reduce the scour depth around bridge pier, several scour reduction measure devises have been proposed such as, collar, bed sill, and pier slot. A lot of studies have been conducted to investigate the efficiency of collar such as in [2-6]. The collar efficiency is slightly related to its thickness $(t c)$, and for 
large value of $(t c / D p)$ the effective pier diameter $(D p)$ increases which causes an increase in scour depth. Bed sill scour reduction measure can be considering as an example of the passive control technique of flow altering reduction measure. There are two types of bed sill scour reduction measures: upstream and downstream. Several research studies were carried out in order to investigate the bed sill efficiency such as in [7-10]. Many studies were carried out in order to investigate the efficiency of slot such as in [11], [3], [8], and [10].

In this study, a Strip Guide Flow Panel (SGFP) device which located at a specified location at the bridge pier has been used to reduce the local scour process effect. The SGFP device is one of the altering scour reduction measure that used adequately to prevent and/or deflect the local scour mechanisms in order to reduce the local scour adjacent to the pier. So this study has been investigated the effect and efficiency of SGFP device in reducing the local scour depth that formed around bridge pier. This study is based on several experimental runs that using a physical hydraulic model. The study is limited to clear water scour condition and a uniform cohesion less material.

\section{Experimental work}

A set of 18 experimental runs were conducted in an open channel flume at the hydraulic laboratory, Department of Civil Engineering, University of Basrah. The flume is $5.72 \mathrm{~m}$ long, $0.61 \mathrm{~m}$ width and $0.97 \mathrm{~m}$ height and is made of fiber glass reinforced plastic with steel reinforcement. The inlet tank $0.2 \mathrm{~m}$ long which located at the downstream side of the flume and the working section is $4.37 \mathrm{~m}$ long and $0.2 \mathrm{~m}$ depth. The working section is filled with sand as bed materials of $8 \mathrm{~cm}$ depth. A pump of maximum capacity $5.4 \mathrm{l} / \mathrm{sec}$ was used to provide water to the flume and the flow rate was controlled by a control valve installed at the inlet pipe. A sharp crested suppressed rectangular weir located at the beginning of the flume was used to measure flow rate $(Q)$.

All experimental runs were conducted with a single cylindrical pier. The cylindrical pier has $22 \mathrm{~cm}$ height and three different diameter $(D p)$ values of 2.5 , $5,7.5 \mathrm{~cm}$ and placed at the midpoint of the working section. All three cylindrical piers were made of wood with smooth surface and painted to prevent any roughness or/and swelling when submerged in water for a long time. The ratio of the flume width to the pier diameter is more than 8 , so that blockage effects were minimized for clear water scour conditions [12].
For all experiments, the SGFP was mounted on the upstream face of cylindrical pier at elevation adjacent to the bed as shown in Figure 1, $A$ and 1, $C$. Three SGFPs were used with one SGFP for every cylindrical pier diameter. All three SGFPs were made of iron arms connected at one of their edged with a constant angle $\left(a_{\mathrm{sg}}\right)$ of $90^{\circ}$. The length of each side $\left(L_{\mathrm{sg}}\right)$ is selected in a way to cover the diameter of the pier as shown in Figure 1, $B$.

A uniform sized sediment with the mean size $\left(d_{50}\right)$ of $0.385 \mathrm{~mm}$ was used as a bed material. The geometric standard deviation of the sediment size $\left(\sigma_{g}=\sqrt{d_{84} / d_{16}}\right)$ is equal to (1.296), which is indicate that the sand is of a uniform size distribution. According to [13], sediment mixture with the value of $\sigma_{g}$ less than 1.4 can be considered as uniformed.

The $D p$ values indicated earlier were carefully chosen so that the effect of sediment size on the local scour can be negligible. The minimum ratio between pier diameter and $d_{50}$ is more than 25 in the present study which satisfy the criteria of Melville and Sutherland as in [14].

Several preliminary experiments were conducted in order to find the discharge calibration curve and the limiting time at which the scour hole will reach the equilibrium state. These experiments reveal that there is a reduction in scour at the upstream nose of the pier at specific time intervals during runs. It is observed that the depth of scour hole increases clearly at the first one-third time period of the experiments' time duration and then becomes approximately constant (or develops at a constant rate). It is concluded that the approximately $95 \%$ of the local scour depth has achieved in 2-hours and this matches the conclusion that reached by Melville and Chiew [15]. For more accuracy of the equilibrium time, 3-hours' time duration is adopted for all experimental runs.

Nine experiments were conducted for case without SGFP device and the other nine ones were conducted for case with SGFP device as shown in Table 1. Same flow characteristics, flow velocity $(V)$ and flow depth $(H)$, were used for every two experiments, with and without SGFP, to study the effect of SGFP on scour process around the pier. All measurements of $V$ and $H$ values, shown in Table 1, were taken after the flow has reached the steady state. The maximum scour depths for cases without and with SGFP, $d_{s}$ and $d_{s w}$ respectively, were measured when the experiments reach the equilibrium time. Hereafter any variable with subscript $(w)$ means that this variable is measured at the case with using SGFP device. 

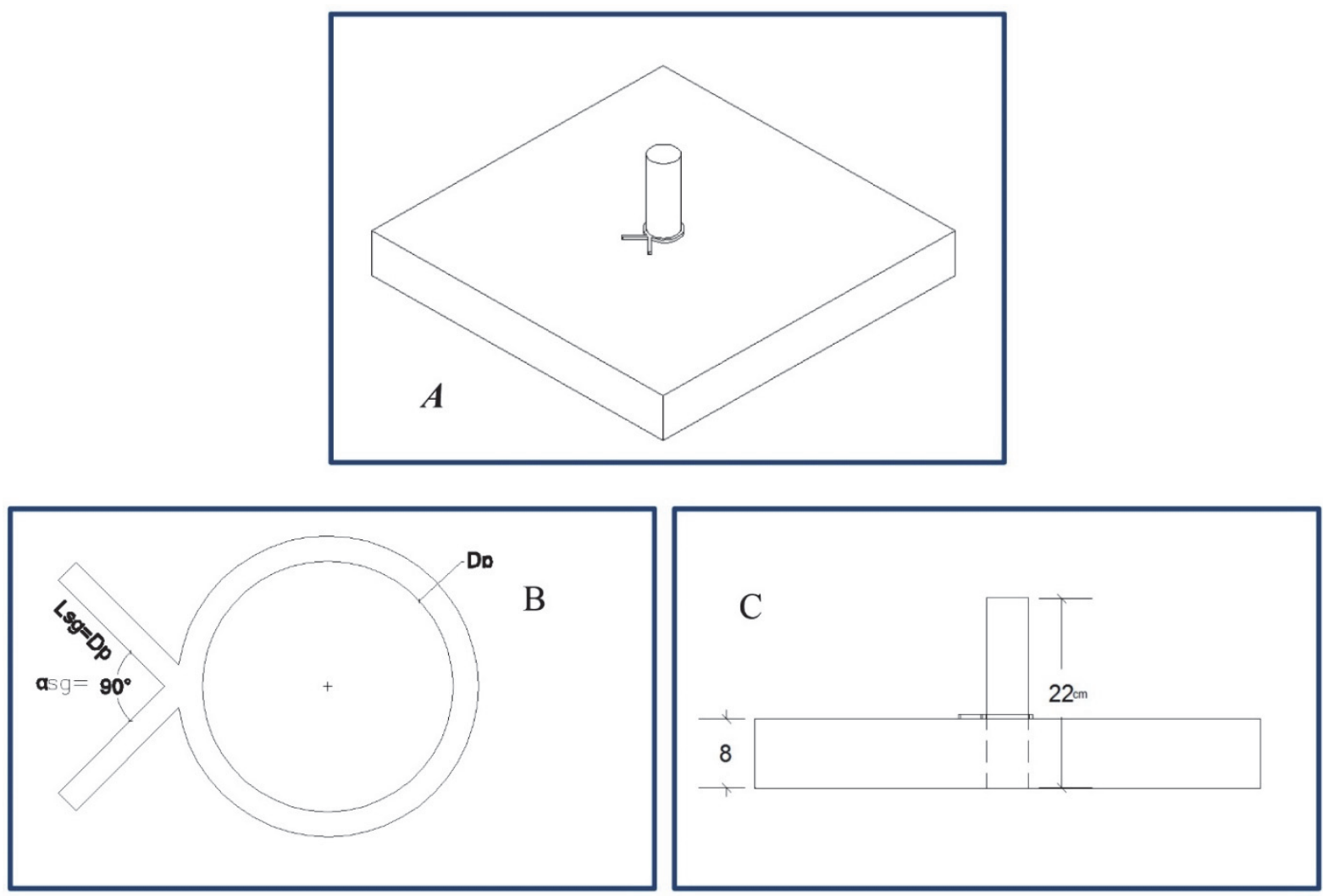

Figure 1. Pier and SGFP configuration

Table 1

Experimental runs data

\begin{tabular}{ccccccc}
\hline $\begin{array}{c}\text { Run number } \\
\text { (without \& } \\
\text { with SGFP) }\end{array}$ & $\begin{array}{c}\boldsymbol{d}_{\mathbf{5 0}} \\
(\mathbf{m m})\end{array}$ & $\begin{array}{c}\boldsymbol{D p} \\
(\mathbf{c m})\end{array}$ & $\begin{array}{c}\boldsymbol{V} \\
(\mathbf{m} / \mathbf{s e c})\end{array}$ & $\begin{array}{c}\boldsymbol{H} \\
(\mathbf{m})\end{array}$ & $\begin{array}{c}\boldsymbol{d}_{\mathbf{s}} \\
(\mathbf{c m})\end{array}$ & $\begin{array}{c}\boldsymbol{d}_{\mathbf{s w}} \\
(\mathbf{c m})\end{array}$ \\
\hline 1 \& 2 & 0.385 & 2.5 & 0.1965 & 0.028 & 1.70 & 0.65 \\
3 \& 4 & 0.385 & 2.5 & 0.2276 & 0.032 & 2.50 & 1.60 \\
5 \& 6 & 0.385 & 2.5 & 0.2531 & 0.036 & 2.80 & 1.80 \\
7 \& 8 & 0.385 & 5.0 & 0.11 .965 & 0.028 & 1.80 & 0.60 \\
9 \& 10 & 0.385 & 5.0 & 0.2276 & 0.032 & 2.60 & 1.00 \\
11 \& 12 & 0.385 & 5.0 & 0.2562 & 0.036 & 3.00 & 1.50 \\
13 \& 14 & 0.385 & 7.5 & 0.2001 & 0.028 & 2.65 & 1.00 \\
15 \& 16 & 0.385 & 7.5 & 0.2327 & 0.033 & 3.90 & 1.90 \\
17 \& 18 & 0.385 & 7.5 & 0.2465 & 0.036 & 4.55 & 2.70 \\
\hline
\end{tabular}

\section{Finding the SGFP performance and critical velocity}

To find the performance of the SGFP, the maximum efficiency, maximum possible and potential maximum scour depths, and safety factor were computed.

The efficiency of the SGFP protection in terms of the maximum reduction in scour depth is computed using the following equation:

$E(\%)=\frac{d_{s}-d_{s w}}{d_{s}} * 100$,

where, $E$ is the efficiency of scour reduction.
Reference [16] proposed the following equation to calculate the maximum possible value of local scour depth $\left(d_{s \max }\right)$ at piers:

$d_{s \max }=2.4 K_{s} * K_{\Theta} * D_{p}$,

where $K_{s}$ and $K_{\ominus}$ are the pier shape and alignment factors and they are equal to 1 for piers of circular cross-section.

To find the potential maximum scour depth $\left(d_{\text {pot }}\right)$ value, the following equation is proposed as in [17];

$\frac{d_{\mathrm{pot}}}{D_{p}}=2.5 \tanh \left[\left(\frac{H}{D_{p}}\right)^{0.4}\right]$.

The Safety Factor (SF) against scouring is calculated using the following equation;

$\mathrm{SF}=\frac{l_{s}}{d_{s}}$,

where $l_{\mathrm{s}}$ represents total penetrating length of pier in soil media and it is equal to $8 \mathrm{~cm}$ in this study.

Reference [18] proposed the following equation to calculate the critical flow velocity:

$\frac{V_{c}}{V_{* c}}=5.75 \log \left(5.53 * \frac{H}{d_{50}}\right)$, 
where $V_{c}$ is the critical flow velocity $(\mathrm{m} / \mathrm{sec}) ; V_{*_{c}}$ is the critical shear velocity $(\mathrm{m} / \mathrm{sec})$ for sediment particles.

Reference [19] proposed the following equation to calculate the $V{ }^{*}$ :

$V_{* c}=0.0115+0.0125 *\left(d_{50}\right)^{1.4} 0.1 \mathrm{~mm}<d_{50}<1 \mathrm{~mm}$

After calculating the $V_{c}$ value, flow intensity $\left(V / V_{c}\right)$ is determined. If $\left(\left(V / V_{c}\right)<0.5\right)$ there is no scour, whereas if $\left(0.5 \leq\left(V / V_{c}\right) \leq 1\right)$ the local scour happens and it is in the type of clear water scour. If $\left(\left(V / V_{c}\right)>1\right)$ the local scour happens and it is in the type of live bed scour as in [20]. Also, if $\left(V \leq V_{c}\right)$ the clear water scour happens, whereas if $\left(V>V_{c}\right)$ the live bed scour happens [21].

\section{Results and discussion}

Any structural elements that have direct contact with water and soil media can suffer from the action of scour processes as a result of flow in porous media, fluid interaction with soil and structure. The purpose of this study is to reduce the scour processes around any constructed pier without damaging it. This can be achieved by using the SGFP to dissipate the flow energy and modifying the flow.

Figure 2 shows the variation of scour depth with time for different pier diameter values with and without using SGFP for constant values of $V$ and $H$. It is shown from this figure that the scour depth increases with increasing in pier diameter for both cases with and without SGFP. For constant $H$, as the pier diameter increases, the pier wetted area increase and this led to increasing in eroding forces that exerted on the sand material close to pier and then increasing the scour depth. For every pier diameter and at every time step, the scour depth for case with SGFP is less than that for the case without SGFP. This means that there is a reduction in turbulence energy and eddies effects at the pier face when using SGFP and it works as an energy dissipater.

Figure 3 expresses the variation of scour depth with time for $D p$ value of $7.5 \mathrm{~cm}$ at different water depth values for cases with and without SGFP. It can be shown from this figure that the scour depth increases with increasing in water depth for both cases with and without SGFP. For constant pier diameter and with increasing in water depth, the wetted area of the pier is increased and this in turn causes an increasing in eroding force at the pier face which causes an increase in scour depth as indicated earlier. Also for every water depth and at every time step, the scour depth for case with SGFP is less than that for the case without SGFP and this means that there is dissipation in turbulence energy due to using the SGFP device.

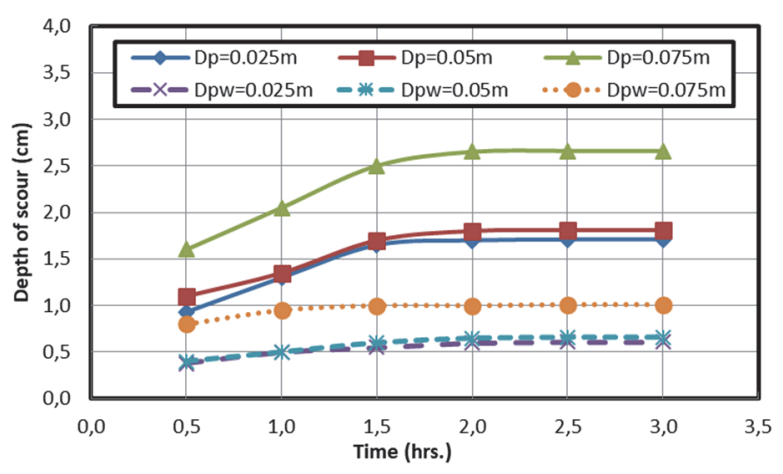

Figure 2. Variation of scour depth with time for different values of pier diameter with (Dpw) and without (Dp) using SGFP $(V=0.196 \mathrm{~m} / \mathrm{sec}, H=0.028 \mathrm{~m})$

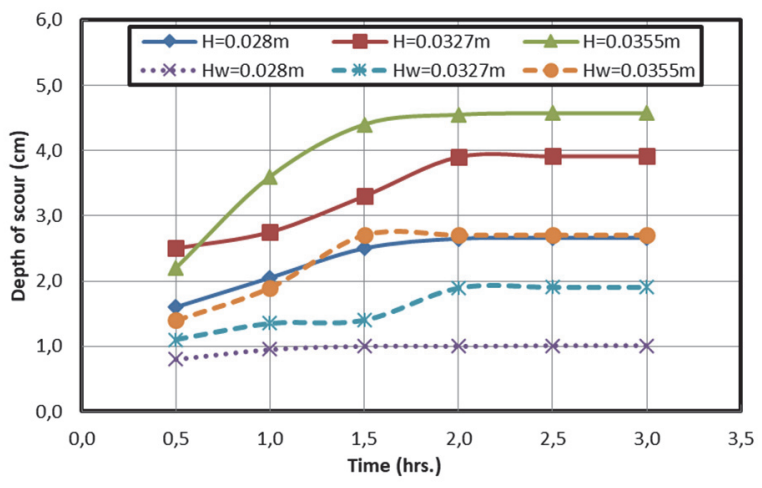

Figure 3. Variation of scour depth with time for different $H$ values with $(H w)$ and without $(H) \operatorname{SGFP}(D p=0.075 \mathrm{~m})$

Figure 4 shows the time variation of scour depth for $D p$ value of $5 \mathrm{~cm}$ with various flow intensity $\left(V / V_{c}\right)$ values for cases with and without SGFP. The $V_{c}$ value is computed using equations 5 and 6 . The flow intensity values of $\left(V / V_{c}=0.88\right),\left(V / V_{c}=1\right)$, and $\left(V / V_{c}=1.11\right)$ represent clear water scour, critical, and live bed scour conditions as indicated earlier. Figure 4 clarifies that the scour depth increases with increasing in flow intensity for cases with and without SGFP. For case without SGFP, there is a high variation in scour depths during the first two hours especially for intensity values of $\left(V / V_{c}=1\right)$, and $\left(V / V_{c}=1.11\right)$ and after that the scour depth becomes approximately constant. Whereas for case with SGFP, the scour depth has less variation for all intensity values during the first two hours and then becomes constant. At all time periods and for the same flow intensity, the scour depth for case with SGFP 
is less than that for case without SGFP. It is very important to take into consideration that the flow velocity and particle size have major effect on flow intensity.

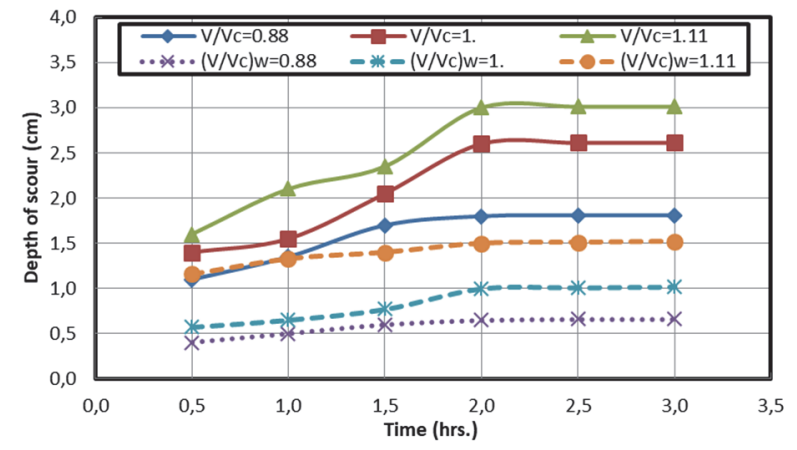

Figure 4. Variation of scour depth with time for different values of flow intensity with $\left(\left(V / V_{c}\right) w\right)$ and without $\left(V / V_{c}\right)$ SGFP $(D p=0.05 \mathrm{~m})$

Figure 5 shows the relationship between scour depth and Froude number $\left(F r=\frac{V}{\sqrt{g H}}\right)$ for pier for cases with and without SGFP. All Fr values are less than 1 , which means that the flow is subcritical. For case without SGFP, it is obvious that the scour depth around pier increases and decreases with a low variation rate when $\mathrm{Fr}$ changes from 0.375 to 0.41 , whereas it increases and decreases with a high variation rate when $\mathrm{Fr}$ changes from 0.41 to 0.43 . Whereas for case with SGFP, the scour depth increases when $F r$ varies from 0.375 to 0.409 and then decreases rapidly when $F r$ is 0.41 . And after that the scour depth takes the same trend as in the case without SGFP but with less values. The same trend of scour depth. The reason for the above relations is related to the complex interaction among the factors the affecting the scour depth and these factors are: geometrical dimensions of pier (pier diameter), bed material (particle size), and flow velocity and water depth.

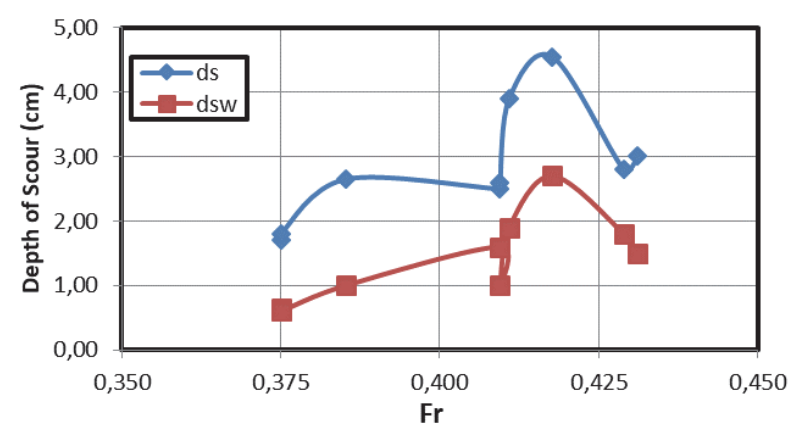

Figure 5. Variation of scour depth with Froud number for cases with and without SGFP
Figure 6 shows the relationship between scour depth and Reynolds number $\left(\left(\operatorname{Re}=\frac{V D_{p}}{v}\right)\right.$ where $v$ is the water kinematic viscosity) for pier with and without SGFP. Generally $R e$ value describes the flow turbulence and represents the capability of water recirculation zone (eddies) to erode bed material. As in Figure 5, Figure 6 expresses a complex nonlinear relationship. It is evident as Reynolds number increases the scour depth will increase take inconsideration the major effect of flow velocity.

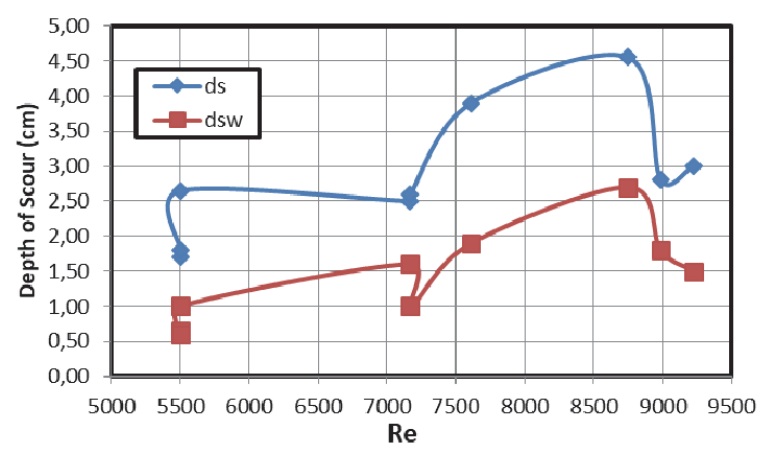

Figure 6. Variation of scour depth with Reynolds number for cases with and without SGFP

Table 2 shows the efficiency $(E)$ of using SGFP and possible maximum $\left(d_{s \max }\right)$ and potential $\left(d_{\mathrm{pot}}\right)$ scour depth values. The above values were computed using equations (1), (2), and (3), respectively. It is clear from Table 2 that the range of $E$ values is between (35.71-66.67\%) which considers a good indicator for adopting the SGFP device to reduce the risk of scour around the pier during the serviceability life of bridge structure. Also it can be shown from this table that the scour depth for case with SGFP $\left(d_{s w}\right)$ gives a good result comparing with the corresponding $d_{s \max }$ and $d_{\text {pot }}$ values.

Table 2

SGFP efficiency, maximum and potential scour depths

\begin{tabular}{|c|c|c|c|c|c|c|c|}
\hline $\begin{array}{c}\text { Run } \\
\text { number } \\
\text { (without } \\
\text { \& with } \\
\text { SGFP) }\end{array}$ & $\begin{array}{c}D p \\
(\mathbf{c m})\end{array}$ & $\underset{(\mathrm{m})}{H}$ & $\begin{array}{c}d_{s} \\
(\mathbf{c m})\end{array}$ & $\begin{array}{c}d_{s w} \\
(\mathbf{c m})\end{array}$ & $\begin{array}{c}E \\
(\%)\end{array}$ & $\begin{array}{l}d_{\text {smax }} \\
\text { (cm) }\end{array}$ & $\begin{array}{r}d_{\text {pot }} \\
(\mathrm{cm})\end{array}$ \\
\hline $1 \& 2$ & 2.5 & 0.028 & 1.70 & 0.65 & 61.76 & 6 & 4.88 \\
\hline $3 \& 4$ & 2.5 & 0.032 & 2.50 & 1.60 & 36.00 & 6 & 5.00 \\
\hline $5 \& 6$ & 2.5 & 0.036 & 2.80 & 1.80 & 35.71 & 6 & 5.11 \\
\hline $7 \& 8$ & 5.0 & 0.028 & 1.80 & 0.60 & 66.67 & 12 & 8.25 \\
\hline $9 \& 10$ & 5.0 & 0.032 & 2.60 & 1.00 & 61.54 & 12 & 8.51 \\
\hline $11 \& 12$ & 5.0 & 0.036 & 3.00 & 1.50 & 50.00 & 12 & 8.81 \\
\hline $13 \& 14$ & 7.5 & 0.028 & 2.65 & 1.00 & 62.26 & 18 & 10.96 \\
\hline $15 \& 16$ & 7.5 & 0.033 & 3.90 & 1.90 & 51.28 & 18 & 11.54 \\
\hline $17 \& 18$ & 7.5 & 0.036 & 4.55 & 2.70 & 40.66 & 18 & 11.81 \\
\hline
\end{tabular}


Table 3

Safety factor of whole system

\begin{tabular}{cccccc}
\hline $\begin{array}{c}\text { Run number } \\
\text { (without } \\
\text { \&ith SGFP) }\end{array}$ & $\begin{array}{c}\text { Dp } \\
(\mathbf{c m})\end{array}$ & $\begin{array}{c}\boldsymbol{d}_{\mathbf{s}} \\
(\mathbf{c m})\end{array}$ & $\begin{array}{c}\boldsymbol{d}_{\mathbf{s w}} \\
(\mathbf{c m})\end{array}$ & $\mathbf{( S F )}$ & $\mathbf{( S F}_{\mathbf{w}}$ \\
\hline 1 \& 2 & 2.5 & 1.70 & 0.65 & 4.71 & 12.31 \\
$3 \& 4$ & 2.5 & 2.50 & 1.60 & 3.20 & 5.00 \\
$5 \& 6$ & 2.5 & 2.80 & 1.80 & 2.86 & 4.44 \\
$7 \& 8$ & 5.0 & 1.80 & 0.60 & 4.44 & 13.33 \\
$9 \& 10$ & 5.0 & 2.60 & 1.00 & 3.08 & 8.00 \\
$11 \& 12$ & 5.0 & 3.00 & 1.50 & 2.67 & 5.33 \\
$13 \& 14$ & 7.5 & 2.65 & 1.00 & 3.02 & 8.00 \\
$15 \& 16$ & 7.5 & 3.90 & 1.90 & 2.05 & 4.21 \\
$17 \& 18$ & 7.5 & 4.55 & 2.70 & 1.76 & 2.96 \\
\hline
\end{tabular}

Table 3 shows the values of safety factor (SF) against scouring for cases with and without SGFP. The SF values were estimated using equation (4). Safety factor with SGFP gives excellent response of pier under turbulent flow regime. Also, as the pier diameter, flow velocity, and depth of water increase the safety factor decreases.

\section{Conclusion}

A series of laboratory experiments were conducted in an open channel flume to study the effect of the SGFP device in reducing the scour effects around a bridge pier. Regardless of using SGFP device, it is found that the scour depth increases with time until it reach the equilibrium value. Also the scour depth increases with increasing in pier diameter, water depth, and flow intensity. Complex non-linear relations were obtained for scour depth versus Froude number and scour depth versus Reynolds number for both cases with and without SGFP device. For the same flow characteristics, flow velocity and depth, the scour depth for case with SGFP was reduced clearly compared with that for case without SGFP. An acceptable range of scour reduction efficiency (35.71-66.67\%) was obtained when using SGFP. Also high safety factors were obtained with adopting SGFP. Also it is found that the scour depth for case with SGFP is small comparing with corresponding potential and maximum scour depth values. This means that the SGFP device has great effect in dissipating the turbulence kinetic energy of vertices and eddies that generated around the pier and in turns reducing the risk of scour.

\section{References}

1. Tafarojnoruz A, Gaudio R, Dey S. Flow-Altering Countermeasures Against Scour at Bridge Piers: Review. Journal of Hydraulic Research. 2010;48(4):441-452.
2. Singh CP, Setia B, Verma DVS. Collar-Sleeve Combination as a Scour Protection Device around a Circular Pier. Proceedings of Theme D, $29^{\text {th }}$ Congress on Hydraulics of Rivers, Water Works and Machinery, Chinese Hydraulic Engineering Society, Beijing, China. 2001;16(21): 202-209.

3. Moncada MAT, Aguirre-Pe J, Bolivar JC, et al. Scour Protection of Circular Bridge Piers with Collars and Slots. Journals of Hydraulic Research. 2009;47(1): 119-126.

4. Shariaty H. Effect of the Shape of the Collar on Local Scour around Bridge Piers (M.Sc. Thesis, Islamic Azad University). 2010.

5. Khassaf SI, Abed MS. Experimental Study of Local Scour around Circular Pier Fitted with Collar. Kufa Journal of Engineering. 2012;3(2):87-100.

6. Nohani E, Bahadoribirgani B, Hahisharafi R. Evaluation and Comparison of Collar and Collar with Slot Methods in Reducing Local Scour of Cylindrical Bridge Piers. Applied Research Journal. 2015;1(5):348-353.

7. Chiew Y, Lim S. Protection of Bridge Piers Using a Sacrificial ill. Water \& Maritime Engineering Journal, Proceedings of the Institute of Civil Engineers, Thomas Telford Journals. 2003;156(1):53-62.

8. Grimaldi C, Gaudio R, Calomino F, et al. Countermeasures Against Local Scouring at Bridge Pires: Slot and Combined System of Slot and Bed Sill. J. of Hydraulic Engineering. 2009;135(5):425-431.

9. Abdulwahed AA. Experimental Investigation of Control Local Scour at Bridge Piers Using Bed Sill (M.Sc. Thesis, Kufa University, Iraq). 2012.

10. Tafarojnoruz A, Gaudio R, Calomino F. Evaluation of Flow-Altering Countermeasures against Bridge Pier Scour. J. of Hydraulic Engineering. 2012;138(3):297-305.

11. Chiew YM. Scour Protecting at Bridge Piers. J. of Hydraulic Engineering, ASCE. 1992;118(9):1260-1269.

12. Shen HW, Schneider VR. Local Scour around Bridge Piers. Journal of Hydraulic Division, Proceeding of the ASCE. 1969;95(6):1919-1941.

13. Parker G. Transport of gravel and sediment mixtures. Sedimentation engineering: processes, measurements, modeling and practice, ASCE Manual of Practice. 2008;110:165-251.

14. Melville BW, Sutherland AJ. Design Method for Local Scour at Bridge Piers. J. of Hydraulic Engineering. 1988;114(10):210-1226.

15. Melville BW, Chiew YM. Time Scale for Local Scour at Bridge Piers. Journal of Hydraulic Engineering. 1999;125(1):59-65.

16. Melville BW, Coleman SE. Bridge Scour. Water Resources Publications, LLC; 2000.

17. Ettema R, Constantinrscu G, Melville BW. Evaluation of Bridge Research: Pier Scour Processes and Predictions. NCHRP Web-Only Document 175. 2011. Available from: http://citeseerx.ist.psu.edu/viewdoc/download? doi $=10.1 \cdot 1.463 .6646 \&$ rep $=$ rep $1 \&$ type $=$ pdf 
18. Melville BW, Sutherland AJ. Design method for local scours at bridge piers. Journal of Hydraulic Engineering. 1988;114(10):1210-1226.

19. Melville BW. Pier and abutment scour: Integrated approach. Journal of Hydraulic Engineering. 1997; 123(2):125-136.

20. Breusers HNC, Nicollet G, Shen HW. Local Scour around Cylindrical Piers. J. of Hydraulic Research. 1977; 15(3):211-252.
21. Raudkivi AJ. Functional Trends of Scour at Bridge Piers. Journal of Hydraulic Engineering. 1986;112(1):1-13.

\section{For citation}

Abdulhussein IA, Al-Asadi K, Qasim RM. Pier scouring reduction using a Strip Guide Flow Panel device. RUDN Journal of Engineering Researches. 2019;20(3):229-235. http://dx.doi.org/10.22363/2312-8143-2019-20-3-229-235

Научная статья

\title{
Уменьшение влияния процесса очистки пирса при использовании устройства Strip Guide Flow Panel
}

\author{
Ихсан А. Абдулхусейн, Рафи М. Касим \\ Южный технический университет, Республика Ирак, Басра, ул. Аль-Зубайр \\ Халид Аль-Асади \\ Университет Басры, Республика Ирак, Басра, шоссе Кармат Али
}

История статьи:
Поступила в редакцию: 01 июня 2019
Доработана: 27 июля 2019
Принята к публикации: 06 сентября 2019

Ключевые слова:

уменьшение размыва, опоры моста, гидротехнические сооружения
С целью изучения эффекта использования устройства Strip Guide Flow Panel (SGFP) для уменьшения влияния процесса очистки вокруг пирса был проведен ряд лабораторных экспериментов. Применялись три цилиндрических пирса разного диаметра и три различных устройства SGFP. Каждое устройство SGFP моделировалось с 2 рычагами, соединенными на одном из их краев под прямым углом. Длина каждого рычага была выбрана таким образом, чтобы покрыть диаметр пирса. Каждое устройство SGFP устанавливалось на восходящей поверхности соответствующего диаметра цилиндрического пирса на уровне желоба. В качестве основного материала выступал осадок однородного размера. На основании экспериментальных данных получен приемлемый диапазон снижения влияния очистки $(35,71-66,67$ \%) и высокие коэффициенты гидравлической безопасности при использовании устройства SGFP. Также установлено, что глубина очистки при использовании SGFP мала по сравнению с соответствующими потенциальными и максимальными значениями глубины очистки. Следовательно, устройство SGFP может работать как рассеиватель кинетической энергии турбулентности, уменьшая риск размыва вокруг пирса в течение срока службы мостовой конструкции

\section{Для цитирования}

Abdulhussein I.A., Al-Asadi K., Qasim R.M. Pier scouring reduction using a Strip Guide Flow Panel device (Уменьшение влияния процесса очистки пирса при использовании устройства Strip Guide Flow Panel) // Becтник Российского университета дружбы народов. Серия: Инженерные исследования. 2019. Т. 20. № 3. С. $229-235$. http://dx.doi.org/10.22363/2312-8143-2019-20-3-229-235

\footnotetext{
Ихсан A. Абдулхусейн, доцент департамента экологии и загрязнения окружающей среды Инженерно-технического колледжа Басры Южного технического университета, кандидат технических наук; drengihssan@stu.edu.iq

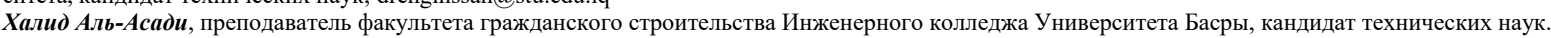

$\boldsymbol{P a ф u}$ М. Касим, преподаватель департамента экологии и загрязнения окружающей среды Инженерно-технического колледжа Басры Южного технического университета, магистр.
} 